\title{
A 12-MONTH SURVEY OF OBSERVATION WARD PRACTICE
}

\author{
BY \\ M. D. EILENBERG*, M. J. PRITCHARD, AND P. B. WHATMORE \\ Maudsley Hospital, London
}

The implications of the Mental Health Act, 1959, have yet to be fully realized, but there is little doubt that re-organization of existing psychiatric services and establishment of new psychiatric units will be required. The intelligent planning of such services requires a basis of factual data. The purpose of the present study is two-fold: first to provide statistical data and secondly to discuss their clinical and administrative relevance. It is thus hoped to provide a base-line relating to psychiatric emergencies upon which some effects of the Mental Health Act, 1959, may be determined. Three aspects of the practice of St. Francis' Hospital Mental Observation Unit during the year 1959-1960 are here presented: the frequency and causal significance of physical disease in psychiatric emergencies; the number and type of Police admissions; and a comparison of informal with statutory admissions.

\section{Historical INTRODUCTION}

The Lunacy Act, 1890, consolidated the Lunacy Act of 1845 and its three amending Acts of 1853 . Before the Local Government Act, 1929, Boards of Guardians were responsible for carrying out the functions of Section 20,21, and 24, the law relating to the immediate disposal of psychiatric emergencies. Patients in these circumstances were admitted to workhouses and there was often little distinction between social care for the poor and medical services for the "pauper lunatic", a situation having its root in the Elizabethan Poor Law Statute of 1601. The Local Government Act, 1929, empowered the London County Council to appropriate to their health service any workhouses used for hospital purposes and Section 19 of the Mental Treatment Act, 1930, allowed the use of these institutions for the detention

*Present address Mayo Clinic, Rochester, Minn., U.S.A. of mental patients. At that time the London County Council inherited from the Board of Guardians twenty units in London consisting of 567 beds, and the L.C.C. Annual Report (1930) described the gross inadequacy of the units and presented plans for the future re-organization of London Observation Wards. The intention was to have six large units of eighty beds each, sited North and South of the river in equal numbers, with consultant psychiatric staff and psychiatric social workers in attendance. The secondo world war interrupted these plans and the National Health Service Act, 1946, prevented their furthero realization, though in 1936 the Council did open a new unit of 76 beds North of the river. Before the Mental Health Act, 1959, six units existed in London, four attached to geriatric or general hospitals, one to a mental hospital in Metropolitan London, and the last to an undergraduate teaching hospital; these six units contained a total of 224 beds. The National Health Service Act, 1946, placed hospitals under the control of the Minister of Health and this necessitated a re-writing of Section 20 of the Lunacy Act, 1890. Workhouses ceased to exist and the opportunity was taken of introducing Section 21A (extension of a 3-day order for a further 14 days by the Medical Officer) to replace Section 24.

The Mental Health Act, 1959, repealed all previous lunacy, mental treatment, and mental deficiency legislation. It permits, and indeed encourages, as much treatment as possible on an informal basis in any hospital or nursing home. Where, however, compulsory admission is necessary, this may be of three kinds: admission for observation for a period not exceeding 28 days (Section 25), admission for treatment for a period of one year in the first instance (Section 26), and emergency admission for 3 days (Section 29). Both observation and treatment orders require the written recommendation of two medical practitioners, one of whom must be approved for the 
purpose by the local health authority. The emergency order, however, requires the signature of only one doctor who will usually be the patient's own general practitioner. This last will probably be the most usual mode of compulsory admission to the Observation Unit and corresponds with the old 3-day order of the Duly Authorized Officer (D.A.O.). The chief difference is that the responsibility of deciding the necessity for admission now rests with the doctor and not with the D.A.O. (or Mental Welfare Officer as he is now known).

\section{REVIEW OF THE LITERATURE}

Despite an annual intake of some 5,000 patients into London Observation Units over many years there are few reported studies. Previous papers deal with two themes: social and administrative arrangements, and clinical studies.

Mapother (1929a), Pentreath and Dax (1937), and more recently Dunkley (1954-57) and Asher (1954, 1957) pointed to the professional advantages for the psychiatrist and for his medical and surgical colleagues when observation wards are attached to general hospitals. The Board of Control (1936) made a systematic examination of observation wards and found many inadequacies. The functions of the observation ward vis $\dot{a}$ vis treatment or diagnosis and disposal were discussed by Mapother (1929a), a Lancet Editorial (1936), and Blacker (1946). Mapother noted that one-third of such patients were discharged home or to non-psychiatric institutions. Pentreath and Dax (1937) published a comprehensive study of St. Francis' Observation Unit, describing the admission procedure, the type of case admitted, and their subsequent disposal. Butler (1940) presented to the Royal Society of Medicine a similar paper from the same Unit. It is of particular interest that the informal admission of patients to an emergency unit under the Mental Health Act, 1959, was foreshadowed by Pentreath and Dax, who admitted "patients of their own accord" - not of voluntary status. In 1954 the Ministry of Health published figures derived from a survey of observation wards in sixty metropolitan and provincial institutions. Herd and Shaddick (1958) analysed statistically the returns of Duly Authorized Officers during 1956 and considered "that a period of delay resulting from admission to an Observation Unit materially reduced the chance of certification". Norris (1959) gave a statistical analysis of the clinical records, social background, and subsequent history of 9,001 patients admitted to two large London observation wards during 1947, 1948, and 1949. In her section on the "utility and futility of Observation Wards", she demonstrated that the observation wards in question saved 35 mental hospital beds each year, and that annually some $1,000-1,500$ patients were saved the necessity of going to a mental hospital.

Of clinical studies, those of Mapother (1929b, 1934) on "Alcoholic Morbidity" and "Sudden Insanity" respectively were based on Observation Ward experience. Post (1951) carried out a clinical and social analysis of 226 admissions to an observation ward

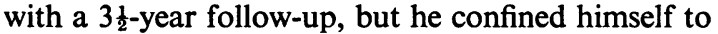
patients over 60 years of age. The prognostic significance of "functional illness" as against "organic syndrome" was seen in the mortality rate of 27 per cent. for the former and 60 per cent. for the latter. Stokes, Nabarro, Rosenheim, and Dunkley (1954) analysed physical illness in an observation ward over a 5-year period. In 54 patients death was due to physical illness, unrecognized before admission, and thirty of the 54 patients were admitted from general hospitals. These authors made a special plea for the wider recognition of mental symptoms in physical illness. Crawford (1954) briefly listed physical diseases seen in a 6-month period during 1949 at the observation unit here studied. He found that 29 per cent. of 248 patients had physical illness, the overall mortality rate being $9 \cdot 2$ per cent.

Steel (1960) and Bockner and Coltart (1961) presented two clinical studies of 27 patients with a diagnosis of neurosyphilis admitted to two observation units during 1957, 1958, and 1959, and cautioned against the tendency to assume that neurosyphilis is nowadays a rare disorder. Gooddy, Gautier-Smith, and Dunkley (1960), from the same unit as Steel, described the experience of a visiting neurologist over a 6 to 7 year period, and noted that neurological lesions were present in about 5 per cent. of 8,000 patients.

\section{DESCRIPTION OF UNIT}

The observation ward studied is an 82-bedded unit of two wards (41 males, 41 females) sited in SouthEast London; it provides a 24-hour service 7 days a week for the reception of psychiatric emergencies throughout the Metropolitan area of London. Admission until November, 1959, was by a 3-day order of the police or D.A.O. under Sections 20 and 21 of the Lunacy Act, 1890. Since November, 1959, informal patients have also been accepted (Mental Health Act, 1959). The Unit is medically staffed during the day by a senior registrar and three registrars, all of whom have had post-graduate experience in medicine 
and are undergoing psychiatric training at the associated Maudsley Hospital; consultant psychiatrists pay weekly visits. Night and week-end duties are performed by registrars seconded from the Maudsley Hospital who remain resident for the period of their duty. Nursing personnel, two psychiatric social workers, and two secretaries complete the staff. The Unit preserves its traditional role of diagnosis and disposal. Its association with a general hospital affords both laboratory facilities and consultant opinion on physical diseases as well as the daily services of two occupational therapists.

\section{METHODOLOGY}

(1) Causal Significance of Physical Disease in PSYCHIATRIC ILLNESS.-All case records of patients admitted to the observation unit between April 1, 1959, and March 31, 1960, inclusive were examined by one of us (P.B.W.) and the case notes of three random samples each of one hundred cases, admitted during the same period, were scrutinized by another of us (M.D.E.) as a check. All patients having a physical disease were selected and these were subdivided into two groups: those in whom this was considered to be merely an associated disorder, and those in whom it was considered causative in producing the psychiatric illness (referred to below as "related").

(2) Police Admissions.-Data were obtained (P.B.W.) on all patients admitted directly on a Police Order during the same period as for Section 1. Data for comparison were obtained by the kind co-operation of the physicians-in-charge of the remaining observation units in London.

(3) Informal Admissions. - The third group studied (M.J.P.) consisted of the first 100 patients admitted informally (from November 21, 1959, to May 14, 1960); this constituted $16 \cdot 2$ per cent. of the total number of patients admitted during that period. The sex ratio (Male:Female 1·63:1) was the reverse of that found in the compulsory admissions during the same period (Male:Female $1: 1 \cdot 36$ ), the difference being significant $(P<0.001)$. As some of the differences between the informal and compulsory admissions might reflect only differences of sex ratio, it was decided that the group of compulsory admissions should be controlled for this item. This was done by taking the next compulsorily admitted patient of the same sex who followed each informally admitted patient. The $\chi^{2}$ technique was used in calculating statistical significance where applicable.

\section{RESULTS}

(1) Causal Significance of Physical Disease IN Psychiatric Illness. - Of the total number of patients admitted, 18.4 per cent. had some physical disease, although in only $7 \cdot 2$ per cent. was the psychiatric disorder secondary to a physical disease, i.e. the "related" group. As only 7.8 per cent. of total admissions for the year were of patients aged 65 years or over, the incidence of physical illness is not explained by the age distribution alone (Table I).

TABLE I

INCIDENCE OF "RELATED" AND “UNRELATED" PHYSICAL DISEASE

\begin{tabular}{|c|c|c|c|c|c|c|c|}
\hline \multirow{2}{*}{\multicolumn{2}{|c|}{ Sex }} & \multicolumn{2}{|c|}{ Male } & \multicolumn{2}{|c|}{ Female } & \multicolumn{2}{|c|}{ Total } \\
\hline & & No. & $\begin{array}{l}\text { Per } \\
\text { cent. }\end{array}$ & No. & $\begin{array}{c}\text { Per } \\
\text { cent. }\end{array}$ & No. & $\begin{array}{l}\text { Per } \\
\text { cent. }\end{array}$ \\
\hline \multirow{3}{*}{$\begin{array}{l}\text { Physical } \\
\text { Disease }\end{array}$} & Related & 46 & $8 \cdot 2$ & 44 & $6 \cdot 2$ & 90 & $7 \cdot 2$ \\
\hline & Unrelated & 39 & $7 \cdot 0$ & 103 & $14 \cdot 7$ & 142 & $11 \cdot 2$ \\
\hline & Total & 85 & $15 \cdot 2$ & 147 & $20 \cdot 9$ & 232 & $18 \cdot 4$ \\
\hline \multicolumn{2}{|c|}{ No Physical Disease } & 473 & $84 \cdot 8$ & 554 & $79 \cdot 1$ & 1,027 & $81 \cdot 6$ \\
\hline \multicolumn{2}{|c|}{ Total } & 558 & 100 & 701 & 100 & 1,259 & 100 \\
\hline
\end{tabular}

The actual physical disease is shown in Table II. The fifteen miscellaneous cases included chronic nephritis, cirrhosis of the liver, erythema multiforme, Crohn's disease, cataract (5), peptic ulcer (2), glaucoma, pediculosis corporis and capitis, and uraemia (2). The total figures do not coincide with the number of 232 patients with physical disease given in Table I, as some had more than one. The approximate percentage of 7.5 per cent. for neurological diseases (including "related epilepsy, neurosyphilis, and alcoholism) can be compared with the 5 per cent. quoted by Gooddy and others (1960), epilepsy contributing the largest proportion in both studies.

\section{TABLE II}

TYPES OF PHYSICAL DISEASE

\begin{tabular}{|c|c|c|c|c|c|}
\hline Diagno & & & & No. & Per cent. \\
\hline 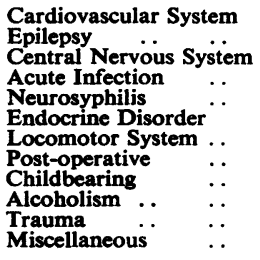 & $\begin{array}{l}\cdots \\
\cdots \\
\cdots \\
\cdots \\
\cdots \\
\cdots \\
\cdots \\
\cdots\end{array}$ & $\begin{array}{l}\cdots \\
\cdots \\
\cdots \\
\cdots \\
\cdots \\
\cdots \\
\cdots \\
\cdots\end{array}$ & $\begin{array}{l}\cdots \\
\cdots \\
\cdots \\
\cdots \\
\cdots \\
\cdots \\
\cdots \\
\cdots \\
\cdots\end{array}$ & $\begin{array}{r}99 \\
40 \\
36 \\
18 \\
13 \\
13 \\
9 \\
8 \\
6 \\
6 \\
4 \\
15\end{array}$ & $\begin{array}{r}37 \cdot 1 \\
15 \cdot 0 \\
13 \cdot 4 \\
6 \cdot 7 \\
4 \cdot 9 \\
4 \cdot 9 \\
3 \cdot 4 \\
3 \cdot 0 \\
2 \cdot 2 \\
2 \cdot 2 \\
1 \cdot 5 \\
5 \cdot 7\end{array}$ \\
\hline Total $\ldots$ & .. & . & .. & 267 & $100 \cdot 0$ \\
\hline
\end{tabular}


Of 59 patients ( 28 males, 31 females) whose "related" physical diseases were known at the time of admission (Table III), 44 (74.6 per cent.) had had previous contact with a medical practitioner a short time before admission, whereas of the 31 patients (17 males, 14 females) whose physical diseases were not known until after admission only sixteen $(51 \cdot 6$ per cent.) had had medical contact. The term "diagnosed before admission" does not necessarily imply direct medical contact, however, as the Duly Authorized Officer, or relative, may have been aware of the physical basis of the disease, e.g. epilepsy or alcohol. Awareness of the existence of physical abnormalities by the referring agency was considered sufficient to warrant the patient's inclusion in the category "diagnosed before admission".

\section{TABLE III}

PATIENTS WITH "RELATED" PHYSICAL DISEASES CLASSIFIED AS DIAGNOSED OR UNDIAGNOSED BEFORE ADMISSION

\begin{tabular}{|c|c|c|c|}
\hline \multirow{2}{*}{ Diagnosis } & \multicolumn{2}{|c|}{ Time of Diagnosis } & \multirow{2}{*}{ Total } \\
\hline & $\begin{array}{c}\text { Before } \\
\text { Admission }\end{array}$ & $\begin{array}{c}\text { After } \\
\text { Admission }\end{array}$ & \\
\hline 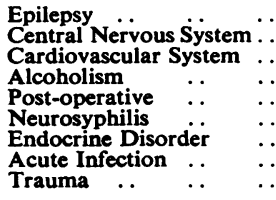 & $\begin{array}{r}19 \\
14 \\
7 \\
5 \\
5 \\
4 \\
3 \\
2 \\
-\end{array}$ & $\begin{array}{l}2 \\
6 \\
7 \\
1 \\
5 \\
2 \\
7 \\
1\end{array}$ & $\begin{array}{r}21 \\
20 \\
14 \\
6 \\
5 \\
9 \\
5 \\
9 \\
1\end{array}$ \\
\hline All Diagnoses $\quad \ldots$ & $\begin{array}{c}59 \\
(65 \cdot 5 \%)\end{array}$ & $\begin{array}{c}31 \\
(34 \cdot 5 \%)\end{array}$ & $\begin{array}{c}90 \\
(100 \%)\end{array}$ \\
\hline
\end{tabular}

The ninety cases with physical diseases "related" to their psychiatric state were next classified into two groups, according to the presence of organic mental symptoms, i.e. disturbed consciousness, disorientation, amnesia, or confabulation (Table IV).

\section{TABLE IV}

PATIENTS WITH PHYSICAL DISEASES "RELATED" TO PSYCHIATRIC DISORDERS CLASSIFIED BY DIAGNOSIS AND BY THE PRESENCE OF ORGANIC MENTAL SYMPTOMS

\begin{tabular}{|c|c|c|c|}
\hline \multirow{2}{*}{ Diagnosis } & \multicolumn{2}{|c|}{ Organic Symptoms } & \multirow{2}{*}{ Total } \\
\hline & Present & Absent & \\
\hline 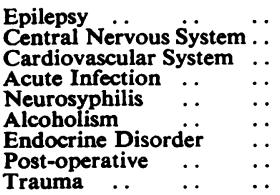 & $\begin{array}{r}11 \\
18 \\
10 \\
6 \\
6 \\
5 \\
1 \\
1\end{array}$ & $\begin{array}{r}10 \\
2 \\
4 \\
3 \\
3 \\
1 \\
4 \\
5 \\
-\end{array}$ & $\begin{array}{r}21 \\
20 \\
14 \\
9 \\
9 \\
6 \\
5 \\
5 \\
1\end{array}$ \\
\hline All Diagnoses $\quad \ldots$ & $\begin{array}{c}58 \\
(64 \cdot 4 \%)\end{array}$ & $\begin{array}{c}32 \\
(35 \cdot 6 \%)\end{array}$ & $\begin{array}{c}90 \\
(100 \%)\end{array}$ \\
\hline
\end{tabular}

Just over one-third of cases with "related" physical diseases had functional symptoms, whereas in just under two-thirds, organic mental features were present. In the diagnostic sub-groups, diseases of the central nervous system and alcoholism produced the greatest proportion of patients with organic mental symptoms.

Table $\mathrm{V}$ shows that forty out of ninety patients with "related" physical diseases were either sent home or sent to a general hospital, i.e. 44 per cent. of these patients required only short-term psychiatric supervision. The average length of stay in the observation ward of patients with "related" physical diseases, who were discharged home or to a general hospital, was 10.9 days. In contrast, patients with "related" physical diseases who were transferred to a mental hospital had an average stay of 19.9 days. During the survey period there were six deaths in the unit, i.e. a mortality rate of 0.42 per cent.

TABLE V

DISPOSAL OF PATIENTS WITH PHYSICAL DISEASES "RELATED" TO PSYCHIATRIC DISORDERS

\begin{tabular}{|c|c|c|c|c|c|c|}
\hline \multirow{2}{*}{\multicolumn{2}{|c|}{ Diagnosis }} & \multirow{2}{*}{$\begin{array}{c}\text { Dis- } \\
\text { charged } \\
\text { Home }\end{array}$} & \multicolumn{2}{|c|}{$\begin{array}{l}\text { Admitted to } \\
\text { Hospital }\end{array}$} & \multirow{2}{*}{ Died } & \multirow{2}{*}{ Total } \\
\hline & & & Mental & General & & \\
\hline $\begin{array}{l}\text { Epilepsy } \\
\text { Central Nervous Syste } \\
\text { Cardiovascular Syste } \\
\text { Acute Infection } \\
\text { Neurosyphilis . . } \\
\text { Alcoholism } \\
\text { Endocrine Disorder } \\
\text { Post-operative .. } \\
\text { Trauma } \quad \text {.. }\end{array}$ & $\begin{array}{l}\cdots \\
\mathrm{em} \\
\cdots \\
\cdots \\
\cdots \\
\cdots\end{array}$ & $\begin{array}{r}14 \\
4 \\
5 \\
1 \\
1 \\
2 \\
2 \\
2 \\
-\end{array}$ & $\begin{array}{r}7 \\
15 \\
8 \\
1 \\
8 \\
3 \\
3 \\
3 \\
-\end{array}$ & $\begin{array}{l}\overline{1} \\
1 \\
- \\
- \\
-\end{array}$ & $\begin{array}{l}- \\
\bar{z} \\
\frac{1}{1}\end{array}$ & $\begin{array}{r}21 \\
20 \\
14 \\
9 \\
9 \\
6 \\
5 \\
5 \\
1\end{array}$ \\
\hline All Diagnoses .. & $\cdots$ & 31 & 48 & 9 & 2 & 90 \\
\hline
\end{tabular}

(2) Police and D.A.O. Admissions.-Table VI shows that St. Francis' admits 54 per cent. of the total police admissions in London.

TABLE VI

POLICE ADMISSIONS TO SECTION 20 BEDS IN SIX UNITS IN LONDON DURING THE 12-MONTH SURVEY

\begin{tabular}{|c|c|c|c|c|c|c|c|c|c|}
\hline \multicolumn{3}{|c|}{ Hospital } & $\begin{array}{l}\text { St. } \\
\text { Fran- }\end{array}$ & $\mathbf{A}$ & B & C & D & $\mathbf{E}$ & Other \\
\hline \multirow{3}{*}{ Sex } & Male & $\begin{array}{c}\text { No. } \\
\text { Percentage } \\
\text { (of Total } \\
\text { Admis- } \\
\text { sions) }\end{array}$ & $\begin{array}{r}139 \\
24 \cdot 9\end{array}$ & - & $\begin{array}{c}31 \\
13 \cdot 0\end{array}$ & $\begin{array}{c}41 \\
11 \cdot 5\end{array}$ & $\begin{array}{c}17 \\
13 \cdot 1\end{array}$ & $\begin{array}{c}47 \\
18 \cdot 4\end{array}$ & $\begin{array}{l}\text { Not } \\
\text { known }\end{array}$ \\
\hline & Female & $\begin{array}{c}\text { No. } \\
\text { Percentage } \\
\text { (of Total } \\
\text { Admis- } \\
\text { sions) }\end{array}$ & $\begin{array}{r}94 \\
11 \cdot 8\end{array}$ & $\begin{array}{r}7 \\
2 \cdot 3\end{array}$ & $4 \cdot 8$ & $\begin{array}{l}12 \\
4 \cdot 2\end{array}$ & $6 \cdot 5$ & $\begin{array}{c}12 \\
15 \cdot 7\end{array}$ & $\underset{\text { known }}{\text { Not }}$ \\
\hline & Both & $\begin{array}{c}\text { No. } \\
\text { Percentage } \\
\text { (of Total } \\
\text { Admis- } \\
\text { sions) }\end{array}$ & $18 \cdot 5$ & $2 \cdot 3$ & 40 & $8 \cdot 5$ & $9 \cdot 2$ & $17 \cdot 2$ & $\begin{array}{c}21 \\
\text { knot } \\
\text { known }\end{array}$ \\
\hline
\end{tabular}


The category "Other" in Table VI includes mental hospitals and observation units in the home counties, which occasionally admit patients from the London postal areas on police orders.

The high percentage of males compared with females is plainly seen in Table VI, but Table VII shows that this sex ratio is reversed in patients admitted on the order of duly authorized officers.

\section{TABLE VII}

SEX RATIO OF PATIENTS ADMITTED BY POLICE AND DULY AUTHORIZED OFFICER (D.A.O.)

\begin{tabular}{|c|c|c|c|c|c|}
\hline \multirow{2}{*}{\multicolumn{2}{|c|}{ Admissions }} & \multicolumn{2}{|c|}{ Police } & \multicolumn{2}{|c|}{ D.A.O. } \\
\hline & & \multirow{2}{*}{$\frac{\text { No. }}{139}$} & \multirow{2}{*}{$\frac{\text { Per cent. }}{59.6}$} & \multirow{2}{*}{$\begin{array}{l}\text { No. } \\
378\end{array}$} & \multirow{2}{*}{$\frac{\text { Per cent. }}{39 \cdot 5}$} \\
\hline \multirow{3}{*}{ Sex } & Male & & & & \\
\hline & Female & 94 & $40 \cdot 4$ & 579 & $60 \cdot 5$ \\
\hline & Total & 233 & 100 & 957 & 100 \\
\hline
\end{tabular}

Table VIII shows the psychiatric diagnoses of these patients. "Affective Illness" is used to describe depressive or manic reactions. "Personality Disorder" includes psychopathy, sexual deviation, alcoholism, or drug addiction; the four cases of neurotic personality presenting with superimposed depression were classified in the category "Personality Disorder". "Organic Disease" includes epilepsy, mental defect, and the symptomatic and organic psychoses. For control purposes 300 D.A.O. patients were randomly selected and the sex ratio ascertained.

There are no obvious diagnostic differences in Table VIII between the police and D.A.O. admissions, though a further breakdown of the group headed "Affective Illness" revealed that 44.6 per cent. of the Police cases had a diagnosis of mania, compared with 17 per cent. of the D.A.O. cases. As a consequence of the behaviour which resulted in admissions to the observation ward, court appearances following discharge for police cases were 1.8 , $0 \cdot 8,0$, and $14 \cdot 8$ per cent. for the four diagnostic categories listed in Table VIII.

TABLE VIII

DIAGNOSIS OF PATIENTS ADMITTED BY POLICE AND DULY AUTHORIZED OFFICER

\begin{tabular}{|c|c|c|c|c|c|}
\hline & \multirow{2}{*}{ Admission } & \multicolumn{2}{|c|}{ Police } & \multicolumn{2}{|c|}{ D.A.O. } \\
\hline & & No. & cent. & No. & cent. \\
\hline \multirow{5}{*}{ Diagnosis } & Affective Illness $\quad$. & 43 & $18 \cdot 4$ & 88 & $29 \cdot 3$ \\
\hline & Schizophrenia & 128 & $54 \cdot 1$ & 155 & $51 \cdot 7$ \\
\hline & Organic Disease $\quad$. & 17 & $7 \cdot 3$ & 8 & $2 \cdot 7$ \\
\hline & Personality Disorder & 47 & $20 \cdot 2$ & 49 & $16 \cdot 3$ \\
\hline & Total & 233 & 100 & 300 & 100 \\
\hline
\end{tabular}

The disposal of these patients is recorded in Table IX. The "Other" disposals include deaths and certifications as defective.

TABLE IX

PERCENTAGE DISPOSAL OF PATIENTS ADMITTED BY POLICE AND DULY AUTHORIZED OFFICER

\begin{tabular}{|c|c|c|c|c|c|c|}
\hline \multicolumn{5}{|c|}{ Admission } & Police & D.A.O. \\
\hline \multirow{2}{*}{$\begin{array}{l}\text { Mental } \\
\text { Hospital }\end{array}$} & \multicolumn{4}{|c|}{ Voluntary Patient or Informal } & $41 \cdot 6$ & $52 \cdot 3$ \\
\hline & \multicolumn{4}{|c|}{$\begin{array}{l}\text { Certified under Section } 16 \text { of } \\
\text { Lunacy Act, } 1890 \quad \ldots \\
\end{array}$} & $27 \cdot 5$ & $19 \cdot 7$ \\
\hline Home .. & $\cdots$ & . & . & $\cdots$ & $28 \cdot 3$ & $28 \cdot 0$ \\
\hline Other .. & $\cdots$ & $\cdots$ & $\cdots$ & $\cdots$ & $2 \cdot 6$ & $0 \cdot 0$ \\
\hline \multirow{2}{*}{ Total } & \multirow{2}{*}{$\cdots$} & \multirow{2}{*}{. } & \multirow{2}{*}{$\cdots$} & Per cent. & 100 & 100 \\
\hline & & & & No. .. & 233 & 300 \\
\hline
\end{tabular}

The higher proportion of Police cases requiring certification compared with that of control group does not reach statistical significance, and a further breakdown revealed that this also applied to all four diagnostic categories, apart from the small "organic" sample of seventeen cases.

Data on D.A.O. cases in Table $X$ were obtained from eighty D.A.O. cases used as controls for sex ratio from Section (3). The clinical impression that 8 patients admitted on Police orders were more aggressive was not confirmed. A diagnostic breakdown showed that "schizophrenic" patients had a higher? proportion of "aggression to others".

TABLE $\mathrm{X}$

BEHAVIOURAL ABNORMALITIES IN PATIENTS ADMITTED BY POLICE AND DULY AUTHORIZED OFFICER

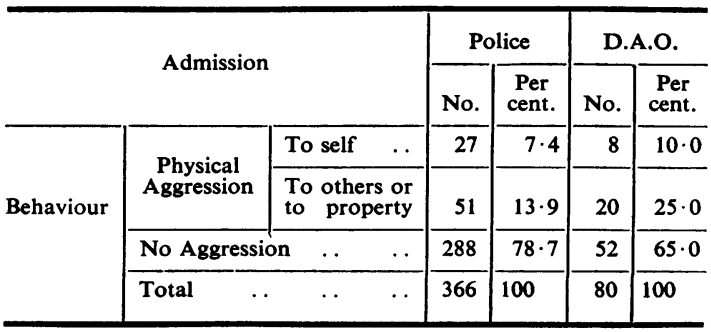

(3) INFORMAL Admissions.-The following points emerge from Table XI (overleaf):

(i) The proportion of psychopaths in the informal group is significantly greater than in the control group $(P<.001)$, and this also applies within each sex (Males $P<\cdot 001$; Females $P<\cdot 05$ );

(ii) The proportion of schizophrenic patients in the control group is significantly greater than in the informal group $(P<\cdot 01)$, but this significance applies only to males $(P<\cdot 02)$; 
TABLE XI

DIAGNOSIS OF INFORMAL ADMISSIONS AND "CONTROL" PATIENTS

\begin{tabular}{|c|c|c|c|c|c|c|c|c|c|}
\hline \multicolumn{2}{|c|}{ Admission } & \multicolumn{4}{|c|}{ Informal } & \multicolumn{4}{|c|}{ Control } \\
\hline \multirow{2}{*}{ Sex } & \multirow{2}{*}{$\cdots$} & \multicolumn{2}{|c|}{ Males } & \multicolumn{2}{|c|}{ Females } & \multicolumn{2}{|c|}{ Males } & \multicolumn{2}{|c|}{ Females } \\
\hline & & No. & $\begin{array}{c}\text { Per } \\
\text { cent. }\end{array}$ & No. & $\begin{array}{l}\text { Per } \\
\text { cent. }\end{array}$ & No. & $\begin{array}{l}\text { Per } \\
\text { cent . }\end{array}$ & No. & $\begin{array}{l}\text { Per } \\
\text { cent. }\end{array}$ \\
\hline \multirow{7}{*}{$\begin{array}{l}\text { Diag- } \\
\text { nosis }\end{array}$} & $\begin{array}{l}\text { Psycho- } \\
\text { pathy }\end{array}$ & 35 & $56 \cdot 5$ & 16 & $42 \cdot 1$ & 11 & $17 \cdot 7$ & 7 & $18 \cdot 4$ \\
\hline & $\begin{array}{l}\text { Schizo- } \\
\text { phrenia }\end{array}$ & 17 & $27 \cdot 4$ & 7 & $18 \cdot 4$ & 30 & $48 \cdot 4$ & 12 & $31 \cdot 6$ \\
\hline & $\begin{array}{c}\text { Depres- } \\
\text { sion }\end{array}$ & 2 & $3 \cdot 2$ & 11 & $28 \cdot 9$ & 6 & $9 \cdot 7$ & 11 & $28 \cdot 9$ \\
\hline & Mania & - & - & - & - & 3 & $4 \cdot 8$ & 3 & $7 \cdot 9$ \\
\hline & $\begin{array}{l}\text { Organic } \\
\text { Disease }\end{array}$ & 3 & $4 \cdot 8$ & 2 & $5 \cdot 3$ & 10 & $16 \cdot 2$ & 4 & $10 \cdot 6$ \\
\hline & Other & 5 & $8 \cdot 1$ & 2 & $5 \cdot 3$ & 2 & $3 \cdot 2$ & 1 & $2 \cdot 6$ \\
\hline & Total & 62 & 100 & 38 & 100 & 62 & 100 & 38 & 100 \\
\hline
\end{tabular}

(iii) No manic patients were admitted informally.

Further examination of the data was made for age distribution, civil status, previous hospital admission, and reason for present admission, in each case by diagnosis and sex. The following points emerged:

(i) In the depressive category, married patients formed a higher proportion of those admitted compulsorily than of those admitted informally, though the difference was not statistically significant.

(ii) A significantly higher proportion $(P<\cdot 05)$ of patients with previous admissions were admitted informally irrespective of diagnosis or sex.

(iii) The compulsory group included a higher proportion admitted for aggressive acts as well as strange behaviour $(P<\cdot 001)$.

No other significant differences were noted.

\section{Acceptance of Medical Advice}

The category "accepting advice" includes the following types of disposal: informal admission to mental hospital, discharge home with out-patient attendance, and discharge by hospital doctor. The term "rejecting advice" includes patients who discharged themselves and those who were certified.

A preliminary breakdown of the data in Table XII for sex did not reveal any notable differences, and these have therefore been omitted.

From Table XII the following points emerge:

(i) No significant difference was found between informal and control patients with regard to "acceptance of further medical advice";
TABLE XII

COMPARISON OF INFORMAL ADMISSIONS AND "CONTROL" PATIENTS ACCEPTING MEDICAL ADVICE (Per cent.)

\begin{tabular}{|c|c|c|c|c|c|c|}
\hline Admission & . & .. & .. & .. & Informal & Control \\
\hline \multirow{6}{*}{ Diagnosis } & \multicolumn{2}{|c|}{ Psychopathy } & . & .. & 55 & 61 \\
\hline & \multicolumn{2}{|c|}{ Schizophrenia } & . & .. & 83 & 71 \\
\hline & \multicolumn{2}{|c|}{ Depression } & . & . & 77 & 94 \\
\hline & Mania & $\ldots$ & .. & .. & - & 67 \\
\hline & \multicolumn{2}{|c|}{ Organic Disease } & $\cdots$ & .. & 100 & 100 \\
\hline & Other & 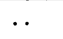 & . & .. & 100 & 100 \\
\hline
\end{tabular}

(ii) Patients in the psychotic categories accepted medical advice more frequently than "psychopaths", whether informally admitted or not;

(iii) There is a tendency, not statistically significant, for the "psychopaths" who were informal patients to accept advice less frequently than those admitted on a police or D.A.O. order, and the reverse held for schizophrenic patients.

Four patients who had no choice of disposal, e.g. returned Section 16, were excluded from Table XII.

\section{Discussion}

Several points of interest arise from the above data. Of patients admitted, 18.4 per cent. had physical diseases, and $7 \cdot 2$ per cent. had physical diseases considered to be of major causal significance in their psychiatric illness. Thus statistical support is given to the opinion of Mapother (1929b), Asher (1954), and other authors, who have emphasized the need for the psychiatric staff to be well trained in general medicine, and have suggested the observation unit should be sited within a general hospital to allow easy access to laboratory facilities and specialist opinion. The present study reveals that a simple psychiatric assessment would have revealed mental symptoms indicative of a physical basis in 58 patients and thus paved the way for further medical evaluation, though the behaviour of some patients with a recognized physical basis for their psychiatric illness might still require transfer to an observation unit. However, forty out of ninety patients in this category were discharged within 11 days, and it is thus conceivable that nursing in a side room of a general ward with visits by an attending psychiatrist would probably provide adequate treatment for the majority of such patients. The low mortality rate of 0.4 per cent. for this Unit compared with $7 \cdot 1$ per cent. in $1947-49$ (Norris, 1959), 4 per cent. 1948-53 (Stokes and others, 1954) and 9. 3 per cent. (Pentreath and Dax, 1937) can best be 
explained by the changing pattern of admissions due to the arrangement of alternative services for the senile group of patients.

The Police admissions were of particular interest as this problem had not previously been dealt with, though throughout London nearly 500 persons are compulsorily placed in Section 20 beds each year. Pentreath and Dax (1937) mentioned the admission rate of 11 per cent. for this group, and this may be compared with $18 \cdot 5$ per cent. for the present study. A statistically higher proportion of such admissions were male $(P<\cdot 05)$, and this is in agreement with the findings of Herd and Shaddick (1958). The comparative survey of admissions by the Police and Duly Authorized Officers reveals that the Police patients tended to be more disturbed and that almost irrespective of diagnosis, more of them required certification $27 \cdot 5: 19 \cdot 7$ per cent. A marked difference was apparent for those patients with a diagnosis of mania; in these the percentages certified were 49 and 17 for Police and D.A.O. admissions respectively. A surprising failure to reveal differences in "aggressive behaviour to others or property" and suicidal attempts was noted. Thus it appears that the cases directly referred by the Police were as well justified as those referred by the D.A.O., and that they will constitute an important proportion of further admissions to Emergency Units. It will be of interest to see whether the intervention of medical contact (Mental Health Act, 1959) before the emergency compulsory admission of non-Police cases will reveal marked differences in the future compared with the "place of safety" admissions (Section 136, Mental Health Act, 1959).

The problems posed in the admission of informal patients to an Emergency Unit were these:

(i) Would such patients constitute a different diagnostic or social group from compulsory patients?

(ii) Would such informal patients later refuse mental hospital admission if this was considered advisable?

(iii) Would the Unit be providing temporary "board and lodging" for a large number of psychopaths.

This latter query was raised by Pentreath and Dax (1937), who referred to "institutional cases" from the casual wards, institutions, and the streets, who were obvious malingerers, often unemployed, and unsuitable for observation ward or mental hospital, and who were rapidly returned to the place they came from.

The present study has revealed few significant differences. The higher proportion of "psychopaths" in the informal group and of schizophrenic patients in the control group was in accordance with expectations as was also the higher proportion of the latter categorized for "aggression to others and/or property". The findings regarding "acceptance of medical advice" seem to be of particular importance. It was considered probable that patients admitted informally would be more likely to accept further medical advice than those admitted compulsorily, but this was not borne out by the study. However, the results revealed that 82.6 per cent. of "informal schizophrenics" and 76.9 per cent. of "informal depressives" had accepted the advice given them, and it seems likely that the relatively small number of patients in these diagnostic categories who rejected advice would have been unsuitable for informal admission to psychiatric hospital anyway, since they would have discharged themselves before they could receive effective treatment.

It is amongst "psychopaths" that the highest proportion of patients "rejecting advice" is found, and this applies to both the informal and the "control" group (45:39 per cent. respectively). As many of the "psychopaths" recovered from the acute disturbances which had necessitated their admission to the observation ward, further treatment had to be arranged for the underlying personality disorder. As facilities for the treatment of psychopaths are limited and the methods as yet inadequate, the lower percentage of such patients accepting advice is perhaps understandable. Even in this group the observation unit may be considered to serve a useful purpose when it provides a sheltered environment in which psychopaths can return in a short time to their premorbid level of social adjustment.

Furthermore, of all informal patients who "accepted medical advice", 28 per cent. did not require further in-patient care and were discharged home, usually within a fortnight of admission. In general, therefore, there are no grounds for disagreeing with the policy of admitting informal patients to an observation ward - a statement that is made explicit in the Memorandum on the Mental Health Act, 1959.

London, with its large population, its proportion of drifting persons of transient or no fixed abode, and its psychiatric hospitals which are distant from the population they serve, presents administrative problems in organizing services for the acute psychiatric emergency which have no counterpart in the rest of Great Britain. Statistical data, such as this paper aims to provide, are indispensable for solving them. 


\section{SUMmary}

A study is presented of three aspects of the practice of a Mental Observation Unit in London during the year 1959-60: organic disease, Police admissions, and informal admissions.

The aim is to provide statistical data against which the effects of the Mental Health Act, 1959, may be judged. The clinical and administrative relevance of the present findings is also discussed.

Our thanks are due to Dr. M. Shepherd, Reader in Psychiatry, Institute of Psychiatry, The Maudsley Hospital, Denmark Hill, S.E.5, for advice and permission to publish, to Miss A. Lawrence, Ph.D. Student, University of London, and to Dr. R. Cawley for guidance on the construction of the Tables.

\section{REFERENCES}

Annual Report by the Commissioners in Lunacy to the Lord Chancellor (1846-1914). H.M.S.O., London.

Asher, R. (1954). Trans. med. Soc., Lond., 70, 93.

- (1957). "Royal Commission in the Law relating to Mental Illness and Mental Deficiency, 1954-1957", Minutes of Evidence, p. 1317. H.M.S.O., London.

Blacker, C. P. (1946). "Neurosis and the Mental Health Services." Oxford University Press, London.

Board of Control (1936). "22nd Annual Report for 1935", (Part 1). H.M.S.O., London.

Bockner, S., and Coltart, N. (1961). Brit. med. J., 1, 18.
Butler, E. N. (1940). Proc. roy. Soc. Med., 33, 725.

Crawford, J. P. (1954). Practitioner, 173, 696.

Dunkley, E. W. "Royal Commission in the Law relating to Mental Illness and Mental Deficiency, 1954-1957", Minutes of Evidence, p. 1203. H.M.S.O., London.

Gooddy, W., Gautier-Smith, P. C., and Dunkley, E. W. (1960), Lancet, 2, 1290.

Herd, J. A., and Shaddick, C. W. (1958). Med. Offr., 100. 233.

Lancet (1936). Editorial, 2, 798.

London County Council Annual Reports, 1930 (publ. 1932); 1931 (publ. 1932-33); 1933 (publ. 1934-35). (1949). "The L.C.C. Hospitals: A Retrospect."

Mapother, E. (1929a). J. roy. san. Inst., 50, 165.

- (1929b). In "Contributions to Psychiatry, Neurology, and Sociology, dedicated to the late Sir Frederick Mott", ed. J. R. Lord for the Mott Memorial Committee. Lewis, London.

(1934). Med. Press, 188, 1.

Maudsley Hospital Medical Superintendent's Reports, 1927-1931; 1932-1935.

Matthews, F. B. (1949). "Mental Health Services." Shaw. London.

Ministry of Health (1955). "Annual Report for 1954". Part II. H.M.S.O., London.

Norris, V. (1959). "Mental Illness in London" (Maudsley Monographs, No. 6). Chapman \& Hall, London.

Pentreath, E. U. H., and Dax, E. Cunningham (1937). J. ment. Sci., 83, 347.

Post, F. (1951). Brit. med. J., 1, 436.

Steel, R. (1960). Lancet, 1, 121.

Stokes, J. F., Nabarro, J. D. N., Rosenheim, M. L., and Dunkley, E. W. (1954). Lancet, 2, 862. 